\title{
Antioxidant property and GCMS profile of oil extracted from Cocos nucifera using a fermentation method
}

\author{
Alabi A. Adenike, Peter Adegbola *, Olumide S. Fadahunsi \\ Ladoke Akintola University of Technology, Ogbomoso, Nigeria
}

\begin{abstract}
Cocos nucifera L. is known as a tree of life because of its economic, domestic, and nutritional usefulness. Coconut oil (CO), which is derived from Cocos nucifera L., has received considerable attention because of its reported folkloric, nutritional, biological, and pharmacological properties. We previously reported the outstanding physicochemical properties of $\mathrm{CO}$; therefore, we analyzed its antioxidant activity and chemical composition in this study. $\mathrm{CO}$ was extracted using a fermentation method with and without applying heat. Its antioxidant activity was investigated using the DPPH free radical scavenging method, the metal chelation capacity, the reduction of antioxidant power, and the nitric oxide scavenging capacity index. The compounds were identified using GC-MS. The data were expressed as a mean \pm SEM and analyzed by one-way analysis of variance (ANOVA) using SPSS 21.0 with data being considered significant at $P<0.05$. The results showed that $\mathrm{CO}$ demonstrated a concentration-dependent DPPH radical scavenging activity and nitric oxide scavenging capacity index, with the highest activity in the heat-extracted virgin $\mathrm{CO}$ (HEVCO). The ferric-reducing antioxidant power and metal chelation capacity significantly varied $(P<0.05)$ between the HEVCO and the cold extracted virgin CO (CEVCO). The GCMS analysis of virgin $\mathrm{CO}$ identified important active compounds. The results revealed a higher content of phenolic compounds in HEVCO compared to CEVCO. In conclusion, applying heat favored incorporating phenolic compounds into $\mathrm{CO}$ and consequently improved the antioxidant potential of HEVCO compared to CEVCO.
\end{abstract}

Key words: Coconut oil; antioxidant; heat; phenolics; extraction; fermentation

\section{Introduction}

Coconut (Cocos nucifera L.) is a member of the Aracaceae (palm) family and is extensively grown in the world's tropical countries (Assa and Konan, 2010). In some parts, coconut tree is referred to as a "tree of life" or a "tree of thousand uses", thus alluding to its economic, domestic, and nutritional usefulness, as well as the significance and importance of all the morphological parts of the tree (Bruce, 2004; Gervajio, 2007). Among the plant's edible products, coconut oil ( $\mathrm{CO}$ ) has gained considerable attention because of its reported folkloric, nutritional, biological, and pharmacological properties (Prades et al., 2012; Shankar et al., 2013). CO is a colorless to pale brownish-yellow oil having a melting point of $23-26^{\circ} \mathrm{C}$ (Bezard et al., 1971; Thampan, 1988). CO is derived by drying and pressing the dry pulp (copra) of coconut at a low temperature; however, there are other methods for extracting $\mathrm{CO}$ that have been previously described in the literature (Aliwalas, 1970; Bernardini, 1970; Cancel et al., 1976; Leonard, 1983). CO is composed of fatty acids of some 12 or fewer carbons, which are known and classified as medium chain fatty acids (MCFA) (Babayan, 1988; Heydnger and Nakhasi, 1996; Conrado, 2003). In addition, there is a significant presence of lauric acid in $\mathrm{CO}$, which prevents the deposition of fats in blood vessels and consequently, prevents the risk of atherosclerosis (Conrado, 2003; Popova, 2011; Moigradean et al., 2013; Orsavova et al., 2015). Furthermore, $\mathrm{CO}$ is reported to be highly resistant to peroxidation, a considerably low cholesterol content, as well as to peroxide and iodine value compared to other oils (groundnut, melon, sunflower, and soybean) (Adegbola et al., 2018). CO has been reported to demonstrate significant beneficial and therapeutic activities such as anti-tumor

${ }^{*}$ Corresponding author: Ladoke Akintola University of Technology, Ogbomoso, Nigeria; e-mail: useablevesselofgod@gmail.com 
(Kopeć et al., 2011), hypocholesterolemic and anti-aging (Adam et al., 2007 ), anti-stress (Nevin and Rajamohan, 2006; Arunima and Rajamohan, 2013; Yeap et al., 2015), hepato-protective (Hanaa et al., 2013; Otuechere et al., 2014), anti-inflammatory and anti-pyretic (Intophuak et al., 2010); wound healing (Nevin and Rajamohan, 2010), blood sugar control (Garfinkel et al. 1992; Kasai et al., 2003) and sight-enhancing (Haliza et al., 2015) activities. These biological potentials are primarily influenced by and attributed to presence of polyphenols, vitamin E, and lauric acid (Adam, 2007; Marina et al., 2009; Arlee et al., 2013 and Yousefi et al., 2013). CO's physicochemical properties were established in our previous study (Adegbola et al., 2018); however, this study evaluated the antioxidant activity and chemical composition of $\mathrm{CO}$, which was extracted by different methods.

\section{Materials and methods}

\section{Materials}

Coconut fruits were purchased from a local market in Esa-Oke, Osun, and all other chemicals that were used were of analytical grade.

\section{Extraction of coconut oil}

Matured coconuts were first crushed to obtain the coconut fruits. Then, the back of the fruits was removed and washed, and the fruits were ground and sieved such that we could obtain some coconut milk. Virgin CO (VCO) was then extracted from the coconut milk using a fermentation method. Subsequently, coconut milk was extracted from freshly harvested coconuts and fermented by airborne lactic acid bacteria for $72 \mathrm{~h}$ (Srivastava et al., 2016), after which the oil phase was separated from the aqueous phase using a syringe. The resultant wet oil was heated at a low temperature for a short time period to remove the moisture and then finally filtered. For extracting the oil without heat, after separating into the oil and aqueous phase, the resultant oil in the upper phase was slowly dispensed using a syringe and then finally filtered (Marina et al., 2009).

\section{$D P P H$ radical scavenging activity of $C O$}

The DPPH scavenging activity was determined using Brand-Williams et al.'s (1995) with slight modification. For preparing the stock solution, $40 \mathrm{mg}$ was dissolved in methanol $(100 \mathrm{ml})$ missing $3.5 \mathrm{ml}$ of the stock solution with methanol, the absorbance was obtained using a UV spectrophotometer at a wavelength of $517 \mathrm{~nm}$. Approximately $100 \mu \mathrm{l}$ of the oil sample with $1 \mathrm{ml}$ methanol DPPH solution was prepared and maintained in the dark for $2 \mathrm{~h}$ to allow the scavenging reaction to occur. The percentage of DPPH scavenging activity was calculated as follows:

DPPH scavenging activity $(\%)=[(A$ blank $-A$ sample $) / A$ blank $]$ $\times 100$

where $A$ is the absorbance.

\section{Ferric Reducing Antioxidant Power of CO}

The ferric reducing antioxidant power (FRAP) of CO was determined using Benzie and Strain's (1996) method as described by Ishtiaq et al. (2014). The FRAP reagent was prepared fresh using a $300 \mathrm{mM}$ acetate buffer at $\mathrm{pH} 3.6$ (3.1 g sodium acetatetrihydrate, $16 \mathrm{ml}$ glacial acid made up to $1: 1$ with distilled water), $10 \mathrm{mM}$ (2,4,6-tris (2-pyridyl)-s-triazine) in $40 \mathrm{mM} \mathrm{HCl}$, and $20 \mathrm{mM} \mathrm{FeCl}_{3} \cdot 6 \mathrm{H}_{2} \mathrm{O}$ in the ratio of $10: 1: 1$ to afford the working reagent. Approximately $100 \mu$ of the extracted sample was added to $1 \mathrm{ml}$ FRAP reagent and the absorbance was measured at $595 \mathrm{~nm}$ after $30 \mathrm{~min}$. Trolox's calibration curve was set up to estimate the activity capacity of the samples. The result was expressed as milligram of Trolox equivalents per 100 gram of the sample (mgTE/100 g of FW).

\section{Determination of metal chelating activity of $\mathrm{CO}$}

\section{Chelation of Metal Ions - Cu${ }^{2+}$}

A violet-colored pyrocatechol reagent was used for determining $\mathrm{Cu}^{2+}$ chelating activity, as described by Saiga et al. (2003). A mixture of $1.0 \mathrm{ml}$ of sodium acetate buffer (100 mM, pH 4.9), $100 \mathrm{ml}$ of $\mathrm{Cu}$ (II) standard solution $(1.0 \mathrm{mg} / \mathrm{ml})$, and $100 \mathrm{ml}$ of the sample $(200 \mu \mathrm{g})$ was prepared in a test tube and allowed to react for $5 \mathrm{~min}$ at room temperature. Then, to the mixture, $25 \mathrm{ml}$ of a violet-colored pyrocatechol solution $(4.0 \mathrm{mM})$ was added and the absorbance was obtained at $632 \mathrm{~nm}$. The chelating activity was extrapolated using the following formula:

Chelating activity $(\%)=(1-$ sample A632/control A632 $) \times 100$

\section{Chelation of Metal Ions $-\mathrm{Fe}^{2+}$}

The method reported by Carter (1971) was used for determining $\mathrm{Fe}^{2+}$ chelating activity. A mixture of $1.0 \mathrm{ml}$ 
of sodium acetate buffer (100 mM, pH 4.9), $100 \mathrm{ml}$ of $\mathrm{Fe}(\mathrm{II})$ standard solution $(1.0 \mathrm{mg} / \mathrm{ml})$, and $100 \mathrm{ml}$ of the sample $(200 \mu \mathrm{g})$ was prepared in a test tube and allowed to react for $5 \mathrm{~min}$ at room temperature. Then, $50 \mathrm{ml}$ of a ferrozine solution $(40 \mathrm{mM})$ was added and the $\mathrm{Fe}^{2+}$ chelating activity was determined by measuring the formation of the $\mathrm{Fe}^{2+}$-ferrozine complex at $562 \mathrm{~nm}$. The following formula was used to extrapolate the

$\mathrm{Fe}^{2+}$ chelating activity $(\%)=(1-$ sample A562/control A562 $) \times 100$ where control A562 is the absorbance of control reaction (without sample) and sample A562 is the absorbance in the presence of a sample.

\section{Nitric oxide radical scavenging activity of $\mathrm{CO}$}

To determine the nitric oxide radical scavenging activity, reaction mixtures containing $2.0 \mathrm{ml}$ of $10 \mathrm{mM} \mathrm{NaN}_{3}$ in a phosphate-buffered saline $(\mathrm{pH}=7.4)$ and $1.0 \mathrm{ml}$ of various concentrations $(20-80 \mu \mathrm{g} / \mathrm{ml})$ of the oil were incubated at $25^{\circ} \mathrm{C}$ for $150 \mathrm{~min}$. Next, $1.0 \mathrm{ml}$ of $0.33 \%$ sulfanilic acid in $20 \%$ glacial $\mathrm{CH}_{3} \mathrm{COOH}$ was added to $0.3 \mathrm{ml}$ of the incubated solution and allowed to stand for $5 \mathrm{~min}$. Then, $0.5 \mathrm{ml}$ of $0.1 \%(\mathrm{w} / \mathrm{v})$ napthylethylenediamine dihydrochloride was added to the mixture and incubated at $25^{\circ} \mathrm{C}$ for $30 \mathrm{~min}$ (Kuate et al., 2010; Kumar et al., 2010). The absorbance was measured at $\lambda_{\max }=540 \mathrm{~nm}$ using quercetin as a blank. Then, the nitric oxide scavenging capacity index (NOSCI) of the oil sample was calculated as follows:

NOSCI $\%=(1-$ absorbance of test $) /$ absorbance of blank $) \times 100$

The NOSCI\% was expressed as scavenging capacity index $\left(\mathrm{SCI}_{50}\right)$, which is defined as the concentration $(\mu \mathrm{g} / \mathrm{ml})$ of the extract required to scavenge $50 \%$ of $\mathrm{NO}^{-}$.

\section{GCMS analysis of $\mathrm{CO}$}

The detection of compounds in VCO was performed on a GC-MS system (Agilent Technologies 7890A coupled with MSD VL5975C) with HP5MS column $(30 \times 0.0320 \mathrm{~mm} \times 0.25 \mu \mathrm{m})$ we used He as the carrier gas at a constant flow rate of $2 \mathrm{ml} / \mathrm{min}$. The sample injection volume was $1 \mathrm{ml}$, and the oven temperature was programmed to $80^{\circ} \mathrm{C}$ for $2 \mathrm{~min}$ at a rate of $10^{\circ} \mathrm{C} / \mathrm{min}$ to $240^{\circ} \mathrm{C}$ with a holding time of $6 \mathrm{~min}$. The samples were then run at a mass spectral scan range of $35-550(\mathrm{~m} / \mathrm{z})$. The compounds were then identified by comparing the spectrum of the separated components with that of MS library 2014, the National Institute of Standards and Technology (NIST), Maryland, USA.

\section{Statistical analysis}

All data were expressed as mean \pm SEM. The values were analyzed by one-way analysis of variance (ANOVA) using Statistical Package for Social Sciences (SPSS) 21.0. The difference between the means was analyzed by Duncan's multiple range test (DMRT) at $P<0.05$.

\section{Results and discussion}

\section{DPPH radical scavenging activity}

The DPPH radical reaction has an advantage that the reaction process is not interrupted by certain side reactions such as metal-ion chelation and enzyme inhibition because of various additives. Moreover, the DPPH test is important because it recognizes free-radical scavenging effects and not pro-oxidant activity (Ruiz et al., 2015). The method is based on the ability of antioxidants to donate protons and thus neutralize the free radical character of the DPPH and produce the non-radical DPPH (Saiqa et al., 2014). Figure 1 shows the DPPH radical scavenging activity of VCO extracted with and without heat. A significant $(P<0.05)$ increase was observed in the activity of $\mathrm{VCO}$ in a concentration-dependent manner. Furthermore, the activity in the HEVCO significantly increased $(P<0.05)$ compared with CEVCO. The highest activity of $10.6 \%$ and $8 \%$ was observed at $80 \mu \mathrm{g} / \mathrm{ml}$ for HEVCO and CEVCO, respectively. The observation made in this study supported the antioxidant activity previously described by Arlee et al. (2013) for VCO extracted using the fermentation method. The oil extracted by the fermentation process goes through various processing steps such as heating during fermentation and drying off water from the oil. Because phenolics are polar, they are easily dissolved in the aqueous phase of coconut milk; thus, the removal of water by heat might have incorporated more phenolic compounds into the HEVCO. Therefore, the removal of water might be responsible for the higher anti-oxidant activity observed in HEVCO.

\section{Nitric oxide radical scavenging activity}

Adegbola et al. (2017) previously reviewed the role of NO radicals in the pathogenesis of diseases such as cardiovascular diseases. They reported that NO plays 


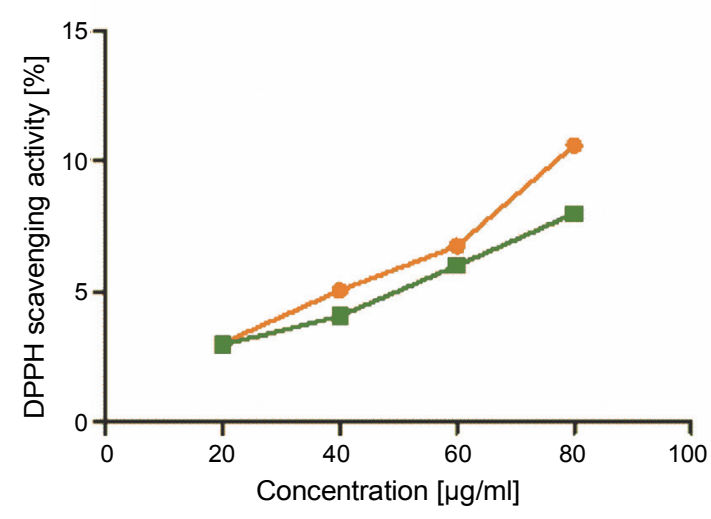

Fig. 1. DPPH radical Scavenging activity of CO extracted by the cold and hot method; the values are expressed as mean \pm SEM and considered significant at $P<0.05$; CEVCO - cold extracted virgin $\mathrm{CO}, \mathrm{HEVCO}$ - hot extracted virgin $\mathrm{CO}$

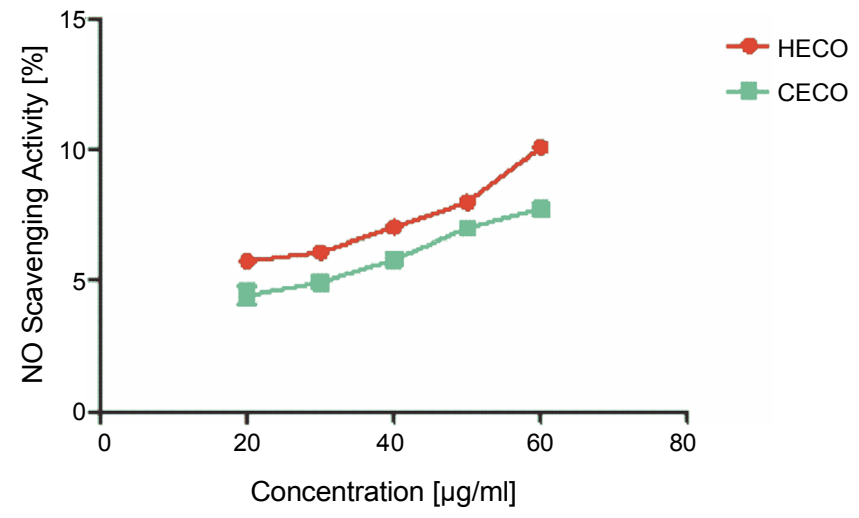

Fig. 2. Nitric oxide radical scavenging activity of $\mathrm{CO}$ extracted by the cold and hot method; the values are expressed as mean \pm SEM and considered significant at $P<0.05$; CEVCO - cold extracted virgin $\mathrm{CO}, \mathrm{HEVCO}$ - hot extracted virgin $\mathrm{CO}$

measured as the equivalent of Trolox. As listed in Table 1 , HEVCO showed the highest ferric-reducing potential of $93.15 \pm 1.20 \mathrm{mg} \mathrm{TE} / 100 \mathrm{~g}$. This ferric-reducing property is by breaking a free radical chain by donating a hydrogen atom (Duh et al., 1999). The metal ion chelating capacity is an important mechanism of antioxidant activity. Transition metals, especially ferrous ions, are potent catalysts that are capable of initiating lipid peroxidation via a Fenton reaction in the cellular membrane (Moguel-Ordóñez et al., 2015). Moreover, ferrous ions can accelerate the peroxidation by the decomposition of lipid hydroperoxides into both alkoxyl and peroxyl radicals that are capable of abstracting hydrogen and initiating the chain reaction of lipid peroxidation (Halliwell, 1991; Chang et al., 2002). The chelation of metal ions is a key strategy to avoid the generation of free radicals that are associated with redox-active metal catalysis (Moguel-Ordóñez et al., 2015). The significant metal ion chelation observed with VCO, the highest in the HEVCO, is an indication of its potential to break the chain of lipid peroxidation (Table 1). Among the various transition metals, iron is known as the most important lipid oxidation pro-oxidant because of its high reactivity (Halliwell and Gutterridge, 1984; Kuate et al., 2010). As observed in this study, VCO is a better $\mathrm{Fe}^{2+}$ chelator with 36.3 $\pm 0.14 \%$ and $15.65 \pm 0.49 \%$ activity than $\mathrm{Cu}^{2+}$ with 31.9 $\pm 0.42 \%$ and $14.55 \pm 0.21 \%$ activity for HEVCO and CEVCO, respectively. Therefore, VCO might be important for limiting lipid peroxidation and consequently prevent associated diseases. The overall antioxidant activity observed in this study supports Srivastava et al. (2016), pyridyltriazine with an intense blue color (Gülçin, 2012) In this study, the ferric-reducing antioxidant power was 
Table 1. Antioxidant activity of $\mathrm{CO}$ extracted by the hot and cold method

\begin{tabular}{c|c|c|c}
\hline Sample & $\begin{array}{c}\text { FRAP } \\
{[\mathrm{mgTE} / 100 \mathrm{~g}]}\end{array}$ & $\begin{array}{c}\mathrm{Cu}^{2+} \text { chelating activity } \\
{[\%]}\end{array}$ & $\begin{array}{c}\mathrm{Fe}^{2+} \text { chelating activity } \\
{[\%]}\end{array}$ \\
\hline HEVCO & $93.15 \pm 1.20^{\mathrm{a}}$ & $15.65 \pm 0.49^{\mathrm{a}}$ & $36.3 \pm 0.14^{\mathrm{a}}$ \\
\hline CEVCO & $90.49 \pm 0.81^{\mathrm{b}}$ & $14.55 \pm 0.21^{\mathrm{b}}$ & $31.9 \pm 0.42^{\mathrm{b}}$ \\
\hline
\end{tabular}

The values are expressed as mean \pm SEM and considered significant at $P<0.05$; the value with different superscripts varied significantly; $\mathrm{CEVCO}$ - cold extracted virgin CO; HEVCO

- hot extracted virgin $\mathrm{CO}$

Table 2. Compounds identified in VCO extracted with cold and heat

\begin{tabular}{l|l}
\hline \multicolumn{1}{c|}{ CEVCO } & \multicolumn{1}{c}{ HEVCO } \\
\hline Hexadecanoic acid, methyl ester & Hexadecanoic acid, methyl ester \\
\hline 10,13 - octadecadienoic acid, methyl ester & 10,13 -octadecadienoic acid, methyl ester \\
\hline 9,12 - octadecadienoic acid (Z,Z), methyl ester & 9,12 -octadecadienoic acid (Z,Z), methyl ester \\
\hline Methyl stearate & Methyl-9-cis,11-trans-octadecadienoate \\
\hline Methyl-18-methylnonadecanoate & 11 -octadecenoic acid, methyl ester \\
\hline Docosanoic acid, methyl ester & Methyl stearate \\
\hline Tetracosanoic acid, methyl ester & Methyl 9-cis, 11, trans, 13, trans-octadecatrienoate \\
\hline & Methyl-18-methylnonadecanoate \\
\hline & Tricyclo-5.2.1.0(2,6) decane, 4-methyl \\
\hline & Docosanoic acid, methyl ester \\
\hline & Tetracosanoic acid, methyl ester \\
\hline & Dodecanoic acid, 1,2,3-propanetriyl ester \\
\hline
\end{tabular}

CEVCO - cold extracted virgin CO; HEVCO - hot extracted virgin CO

study on HEVCO. As previously reported, heat favored the incorporation of additional phenolics into the VCO sample extracted with heat. Therefore, a higher phenolic content of HEVCO could contribute to the observed antioxidant activity.

\section{GC-MS profiles of compounds in $\mathrm{CO}$}

The constituents in VCO were identified using GCMS. The identified compounds in the HEVCO and CEVCO included certain fatty acids, as shown in Table 2. The fatty acid content included palmitic acid (C16:0), stearic acid (C18:0), oleic acid (C18:1), and PUFAs such as linoleic acid (C18:2) and linolenic acid (C18:3). Figure 3 and Figure 4 show the spectra and structure of the identified compounds. Some of these identified compounds have been associated with several biological functions such as antioxidant, anti-inflammatory, antimicrobial, anticancer, and hypocholesterolemic activities
(Yu et al., 2005; Intahphuak et al., 2010; Chandrasekaran et al., 2011; Jegadeeswari et al., 2012; Upgade and Anusha, 2013; Parthipan et al., 2015).

For instance, hexadecanoic acid methyl ester (palmitate ester) was described to be toxic towards bacteria and fungi (Chandrasekaran et al., 2011). Moreover, it was also reported to possess antioxidant and hypocholesterolemic activities (Jegadeeswari et al., 2012; Upgade and Anusha, 2013). The selective cytotoxicity effects of 9,12-octadecadienoic acid (Z,Z), methyl ester (linolate methyl ester), and palmitate ester against cancerous cells established their anti-tumor activity (Harada etal., 2002; Maria etal., 2011; Ravi and Krishnan, 2017). The anti-inflammatory activity of 9,12 - octadecadienoic acid $(Z, Z)$ and methyl ester found in the leaves and stem bark of Pleiospermium alatum and seed of Croton tiglium has been previously reported (Mangunwidjaja et al., 2006). Methyl-9-cis,11-trans-octadecadienoate (rume- 


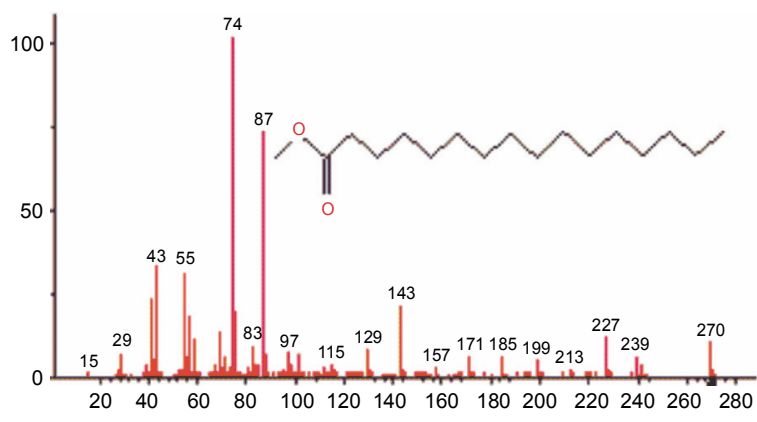

Hexadecanoic acid, methyl ester

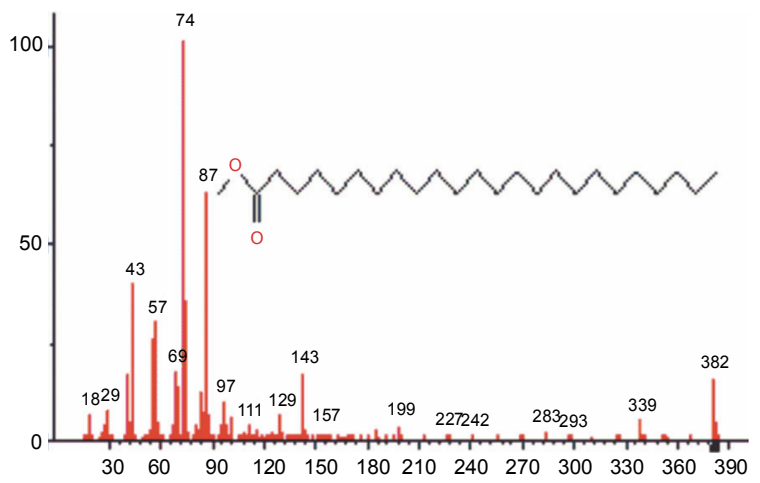

Tetracosanoic acid, methyl ester
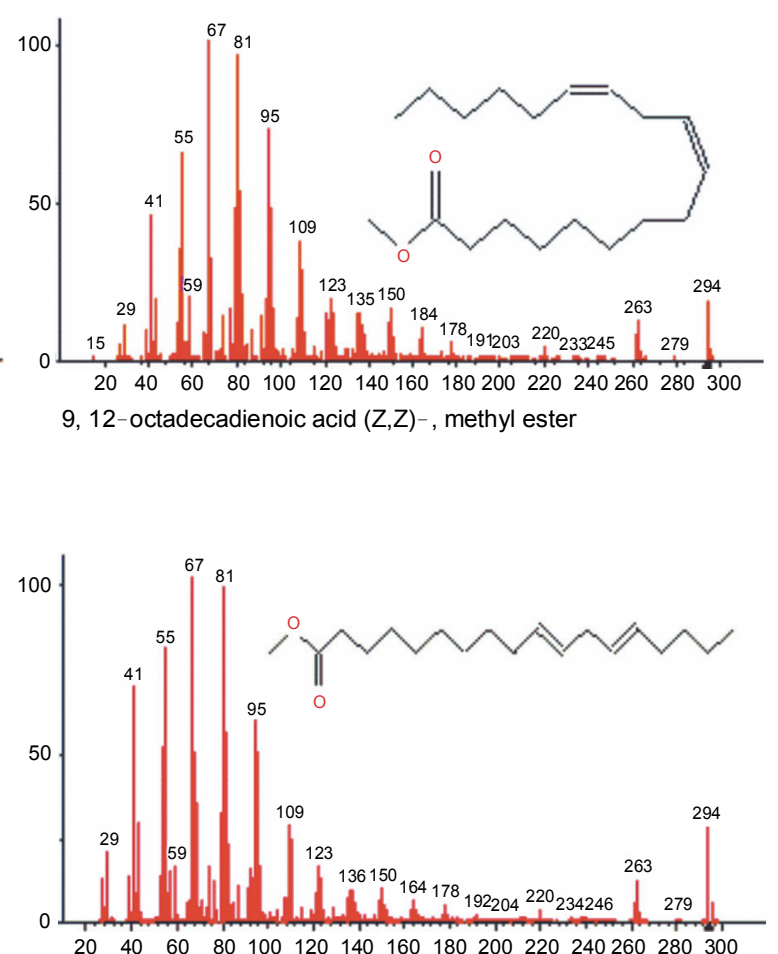

10, 13-octadecadienoic acid, methyl ester

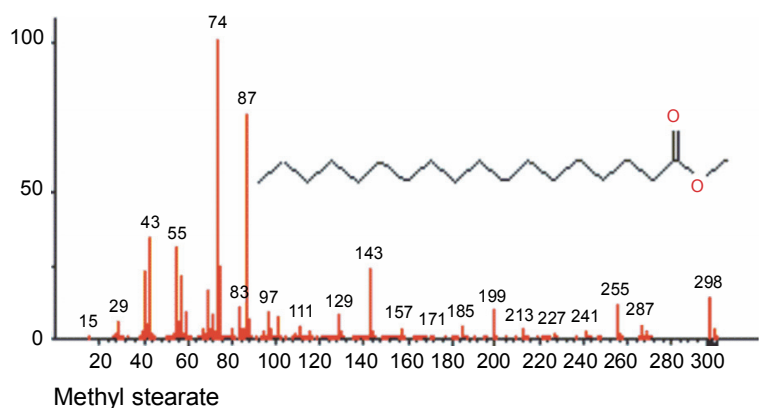

Methyl stearate

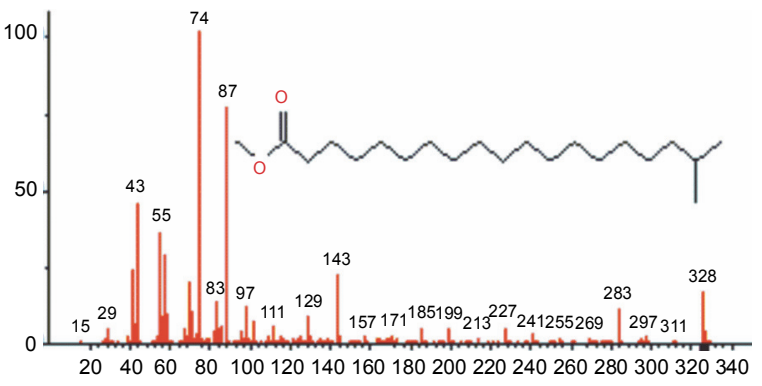

Methyl 18-methylnonadecanoate

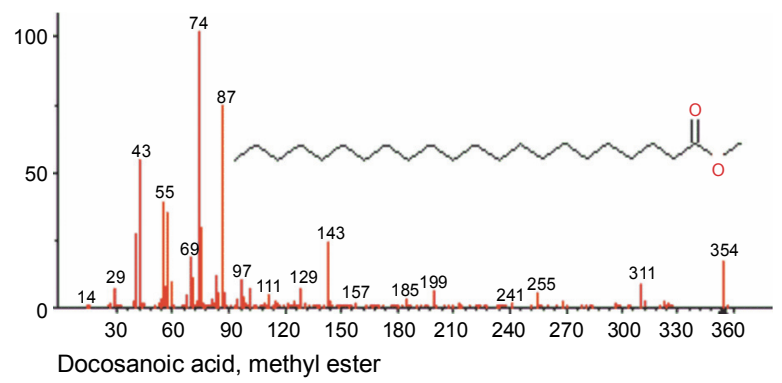

Fig. 3. Spectra and structures of some compounds identified in $\mathrm{CO}$ extracted by the cold method 


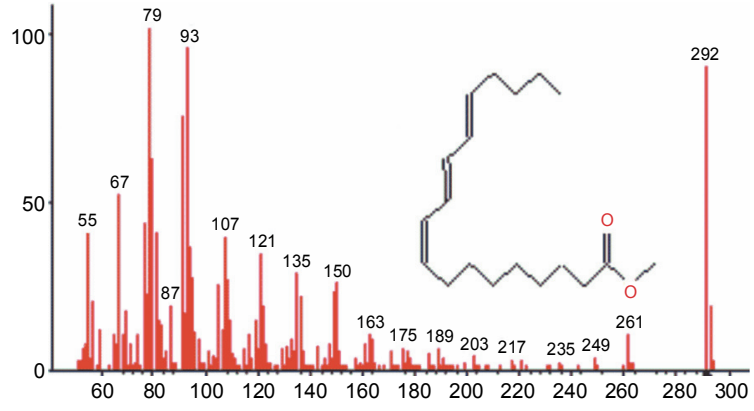

Methyl-9-cis, 11-trans, 13-trans-octadecadienoate

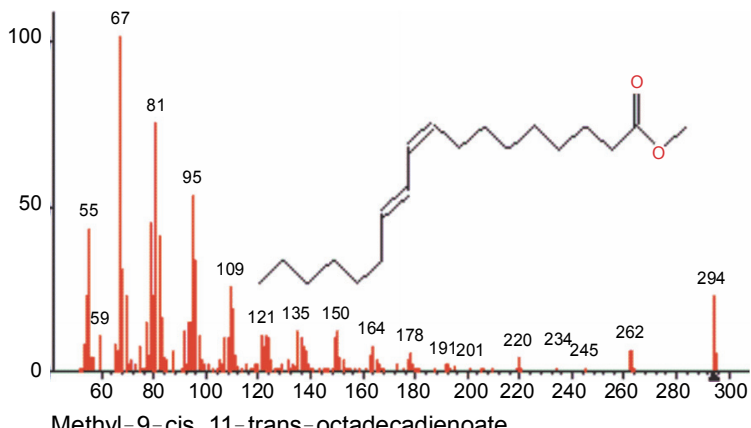

Methyl-9-cis, 11-trans-octadecadienoate

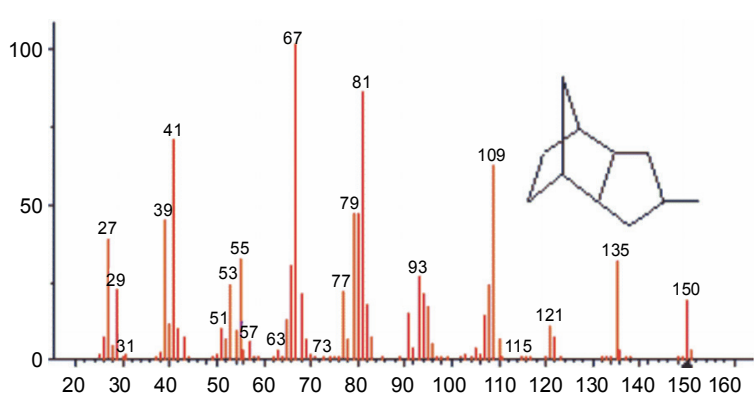

Tricyclo[5,2,1,0(2,6)]decane, 4-methyl-

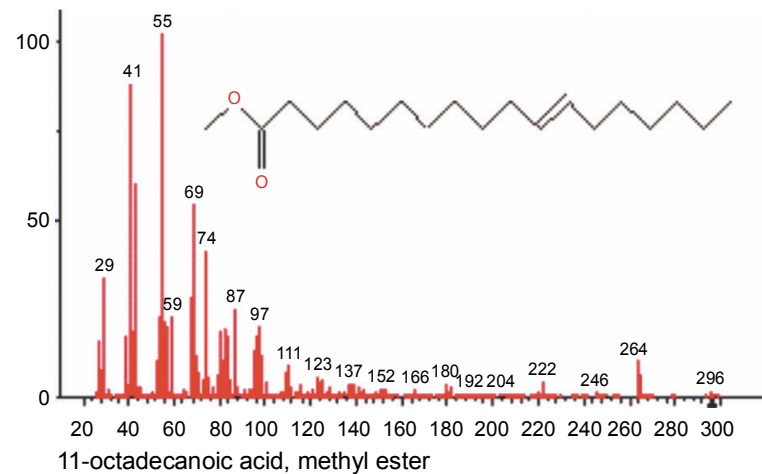

11-octadecanoic acid, methyl ester
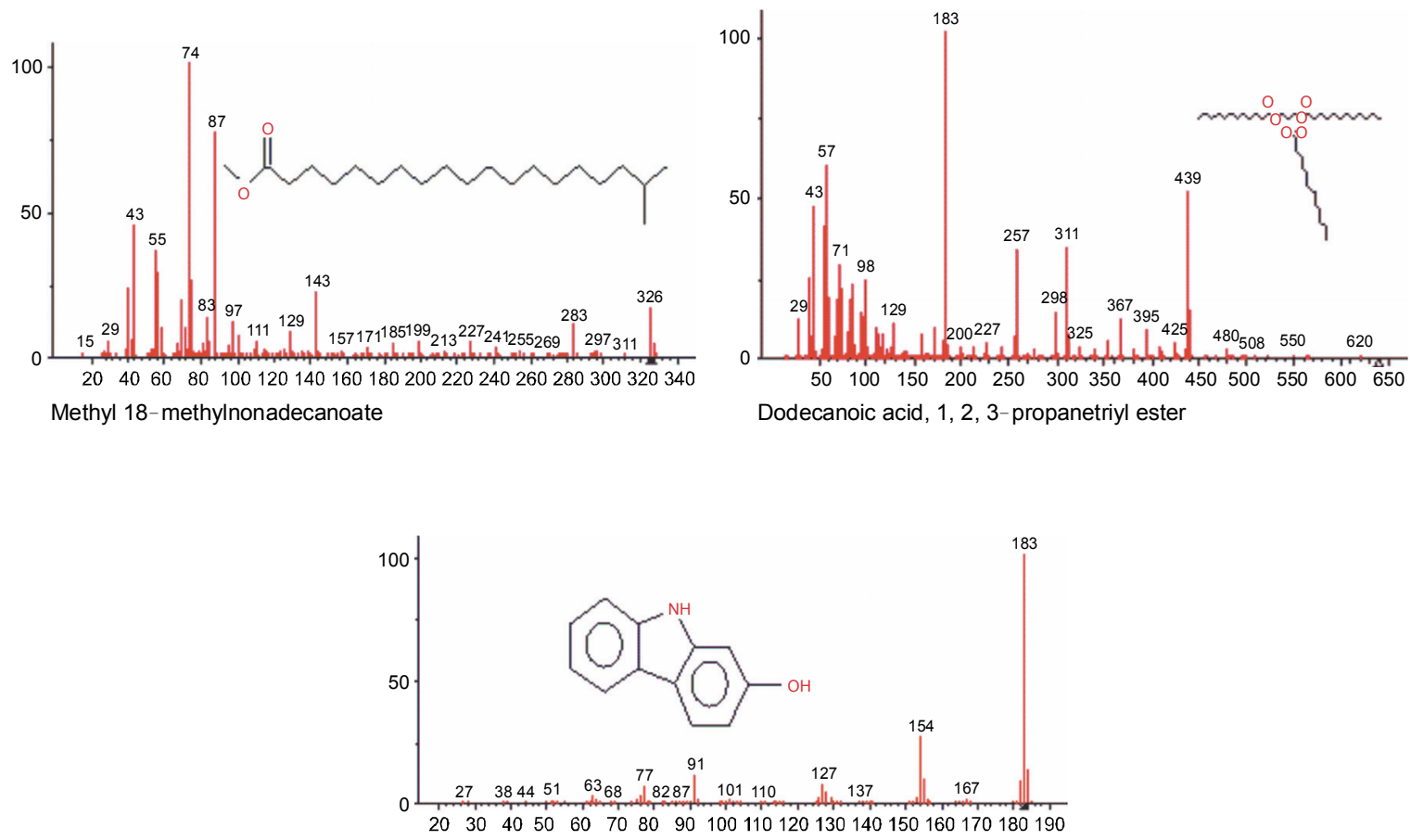

2-hydroxycarbazole

Fig. 4. Spectra and structures of some compounds identified in $\mathrm{CO}$ extracted by the hot method 
nic acid) is an isomer of conjugated linoleic acid (CLA) found in natural products (Kramer et al., 1998) that was reported to possess anti-inflammatory activity (O'Shea et al., 2004). 2-hydroxycarbazole is a phenolic alkaloid belonging to a wide group of compounds called carbazole, which have diverse biological activities such as antioxidative, anti-inflammatory, antibacterial, and cytotoxic activities (Zhang et al., 2010; Bandgar et al., 2012; Biamonte et al., 2013; Peng et al., 2013). The presence of 2-hydroxycarbazole in the HEVCO might have influenced its antioxidant activity via the carbazole $\mathrm{N}-\mathrm{H}$ and hydroxyl moiety. Lauric acid (dodecanoic acid) is one of the most abundant and important fatty acids found in $\mathrm{CO}$ (Ghani et al., 2018). Note that it was not detected by GCMS analysis. Moreover, studies have reported that lauric content of $\mathrm{CO}$ varies with location, the variety of crop (Laureles et al., 2000), age of nuts (Balleza and Sierra, 1976), and time of harvest (Carandang, 2008).

Depending on the extraction method, compounds identified in the VCO varied among the samples, and they were present in higher amounts in HEVCO than in CEVCO. Previously, studies have reported that a higher temperature favors the incorporation of more phenolic compounds into oil (Marina et al., 2009; Srivastava et al., 2016). This might explain the reason for the number of compounds identified in the HEVCO. Because phenolics are polar and are easily dissolved in the aqueous layer of coconut milk, compared to the oil layer during fermentation, some phenolic in CEVCO might have been lost during collection (Arlee et al., 2013).

\section{Conclusions}

This study confirms that $\mathrm{CO}$ has some antioxidant activity, which is responsible for its medicinal and nutritional benefits. In this study, the extraction methods influenced the activity and constituents of CO. Moreover, it is evident that applying heat favored the incorporation of phenolics into $\mathrm{CO}$ and consequently improved the antioxidant activity of HEVCO compared to CEVCO.

\section{References}

Adam S.K., Sulaiman N.A., Mat A.G., Jaarin K. (2007) Heating reduces vitamin $E$ content in palm and soy oils. MJBMB 15: 76-79.

Adegbola P., Aderibigbe I., Hammed W., Omotayo T. (2017) Antioxidant and anti-inflammatory medicinal plants have potential role in the treatment of cardiovascular disease: a review. Amer. J. Cardiovasc. Dis. 7(2): 19-32.

Adegbola P., Fadahunsi O.S., Alabi A.A. (2018) Comparative antioxidant study of ripe and unripe plantain and the qualitative assessment of some food oil extracts. Annals. Food Sci. Technol. 19(4): 758-765.

Aliwalas A.R., Buccat C.P. (1970) Filtration extraction of granulated coconut on a bench scale. Phillip. J. Sci. 96(3): 215-285.

Arlee R., Suanphairoch S., Pakdeechanuan P. (2013) Differences in chemical components and antioxidant-related substances in virgin coconut oil from coconut hybrids and their parents. Food Res. Int. 20(5): 2103-2109.

Arunima S., Rajamohan T. (2013) Effect of virgin coconut oil enriched diet on the antioxidant status and paraoxonase 1 activity in ameliorating the oxidative stress in rats - a comparative study. Food Funct. 4(9): 1402-1409.

Assa R.R., Konan J.L. (2010) Physicochemical characteristics of kernel during fruit maturation of four coconut cultivars (Cocos nucifera L.). Afr. J. Biotechnol. 9(14): 2136-2144.

Babayan V.K. (1988) Medium chain triglycerides. In dietary fat requirements in health and development. Ed. C.J. BeareRogers. AOCS press, Champain, Illinois (USA): 73-86.

Balleza C.F., Sierra Z.N. (1976) Proximate analysis of the coconut endosperm in progressive stages of development. Philippines J. Crop Sci. 1: 37-44.

Bandgar B.P., Adsul L.K., Chavan H.V., Jalde S.S., Shringare S.N., Shaikh R., Meshram R.J., Gacche R.N., Masand V. (2012) Synthesis, biological evaluation, and docking studies of 3-(substituted)-aryl-5-(9-methyl-3-carbazole)-1H-2pyrazolines as potent anti-inflammatory and antioxidant agents. Bioorg. Med. Chem. Lett. 22: 5839-5844.

Benzie I.F.F., Strain J.J. (1996) The ferric reducing ability of plasma (FRAP) as a measure of "antioxidant power": The FRAP assay. Anal. Biochem. 239: 70-76.

Bernardini E. (1970) Direct extraction of oil from oilseeds without pressing. Riv. Ital. Sost. Gras. 47(8): 385-391.

Bezard J., Bugaut M., Clement G. (1971) Triglyceride composition of coconut oil. J. Am. Oil Chem. Soc. 48(3): 134-139.

Biamonte M.A., Wanner J., Le Roch K.G. (2013) Recent advances in malaria drug discovery. Bioorg. Med. Chem. Lett. 23: 2829-2843.

Brand-Williams W., Cuvelier M.E., Berset C. (1995) Use of a free radical method to evaluate antioxidant activity. Lebensmitt.Wissensch. Tech. 28: 25-30.

Bruce F. (2004) The coconut oil miracle. Avery, USA: 1-7.

Cancel L.E., Rosario J.A., Hernandez E.R. (1976) Coconut oil extraction from coconut milk presscake. J. Agric. Uni. Puerto Rico. 60(3): 281-293.

Carandang E.V. (2008) Health benefits of virgin coconut oil. www.pcrdf.org/artimages\%5CVCO.doc.

Carter P. (1971) Spectrophotometric determination of serum iron at the submicrogram level with a new reagent (ferrozine). Anal. Biochem. 40: 450-458.

Chandrasekaran M., Senthilkumar A., Venkatesalu V. (2011) Antibacterial and antifungal efficacy of fatty acid methyl 
esters from leaves of Sesuvium portulacastrum L. Eur. Rev. Med. Pharmcol. Sci. 15: 775-780.

Chang L.W., Ye W.J., Huang S.C., Duh P.D. (2002) Antioxidant activity of sesame coat. Food Chem. 78: 347-354.

Conrado S.D. (2003) Coconut oil: atherogenic or not? (What therefore causes atherosclerosis?). Philipp J. Cardiol. 31(3): 97-104.

Duh P.D., Tu Y.Y., Yen G.C. (1999) Antioxidant activity of the aqueous extracts of harng Jyur (Chrysanthemum morifolium Ramat). LWT - Food Sci. Technol. 32: 269-277.

Garfinkel M., Lee S., Opara E.C., Akwari O.E. (1992) Insulinotropic potency of lauric acid: a metabolic rationale for medium chain fatty acids (MCF) in TPN formulation. J. Surg. Res. 52(4): 328-333.

Gervajio G.C. (2005) Fatty acids and derivatives from coconut oil. John Wiley \& Sons, USA: 1-56.

Ghani N.A.A., ChanniP A.A., Hwa P.C.H., Ja'afar F., Yasin H.M., Usman A. (2018) Physicochemical properties, antioxidant capacities, and metal contents of virgin coconut oil produced by wet and dry processes. Food Sci. Nutr. 6: 1298-1306.

Gülçin I. (2012) Antioxidant activity of food constituents: an overview. Arch. Toxicol. 86(3): 345-391.

Haliza A.M., Sharanjeet K., Ahmad R.G., Ng Chinn H., Nor H.A.S. (2015) Pilot study: the efficacy of virgin coconut oil as ocular rewetting agent on rabbit. Evid. Based Compl. Alt Med. 2015: 135987.

Halliwell B. (1991) Reactive oxygen species in living systems. Source biochemistry and role in human disease. Amer. J. Med. 91: 14-21.

Halliwell B., Gutteridge J.M. (1984) Oxygen toxicology, oxygen radicals, tran-sition metals and disease. Biochem. J. 219: $1-4$.

Hanaa M., Abd E.F., Lamiaa A.A.B. (2013) Hepatoprotective effect of olive and coconut oils against oxidative stressinduced by 2, 4 dichlorophenoxyacetic acid. Indian J. Appl. Res. 3(12): 42-46.

Harada H., Yamashita U., Kurihara H., Fukushi E., Kawabata J., Kamei Y. (2002) Antitumor activity of palmitic acid found as a selective cytotoxic substance in a marine red alga. Antican. Res. 22: 2587-2590.

Heydnger J.A., Nakhasi D.K. (1996) Medium chain triacylglycerols. J. Food Lipids.: 251-257.

Intahphuak S., Khonsung P., Panthong A. (2010) Anti-inflammatory, analgesic, and antipyretic activities of virgin coconut oil. Pharm Biol. 48(2): 151-157.

Ishtiaq S., Ahmad M., Hanif U., Akbar S., Mehjabeen S.H.K. (2014) Phytochemical and in-vitroantioxidant evaluation of different fractions of Amaranthus graecizans subsp. Silvestris (Vill.) Brenan. Asian Pac. J. Trop. Biomed. 4(12): 965-997.

Jegadeeswari P., Nishanthini A., Muthukumaraswamy S., Mohan V.R. (2012) GC-MS analysis of bioactive components of Aristolochia krysagathra (Aristolochiaceae). J. Curr. Chem. Pharm. Sci. 2: 226-236.

Kasai M., Nosaka N., Maki H., Negishi S., Aoyama T., Nakamura M., Suzuki Y., Tsuji H., Uto H., Okazaki M., Kondo
K. (2003) Effects of dietary medium and long-chain triacylglycerols (MLCT) on accumulation of body fat in healthy humans. Asia Pac. J. Clin. Nutr. 12(2): 151-160.

Kopeć A., Nowacka E., Piątkowska E., Leszczyńska T. (2011) Charakterystyka i prozdrowotne właściwości steroli roślinnych. Zywn. Nauk Technol. 3(76): 5-14.

Kramer J.K.G., Parodi P.W., Jensen R.G., Mossobad M.M., Yuraweczd M.P., Adlof R.O. (1998) Rumenic acid: a proposed common name for the major conjugated linoleic acid isomer found in natural products. Lipids. 33(8): 835.

Kuate D., Etoundi B.C.O., Soukontoua Y.B., Ngondi J.L., Oben J.E. (2010) Comparative study of the antioxidant, free radical scavenging activity and human $L D L$ oxidation inhibition of three extracts from seeds of a cameroonian spice, Xylopia parviflora (A. Rich.) Benth. (Annonaceae). Int. J. Biomed. Pharm. Sci. 5(1): 18-30.

Kumar B.S.A., Lakshman K., Jayaveera K.N., Shekar D.S., Kumar A.A., Manoj B. (2010) Antioxidant and antipyretic properties of methanolic extract of Amaranthus spinosus leaves. Asian Pacific J. Tropical Med. 3(9): 702-706.

Laureles L.R., Rodriguez M.A.A., Caraos C.E., Reano G.A., Santos L.A.C., Mendoza E.M.T. (2000) Storage lipid variability in promising coconut cultivars and hybrids: fatty acids and triacylglycerol composition. Philippines J. Crop Sci. 25: 42-54.

Leonard E. (1983) Sri Lankan inventor who makes life easier for his countrymen. Cocomunity, APCC/QS/45/83,33-35.

Mangunwidjaja D.S., Kardono S.R., Iswantini L.B.S.D. (2006) Gas chromatography and gas chromatography - mass spectrometry analysis of Indonesian Croton tigliumseeds. J. Appl. Sci. 6: 1576-1580.

Maria J.R.P., Kannan P.S.M., Kumaravel S. (2011) GC-MS Analysis of Lantana camara L. leaves. JPRD 2(11): 63-66.

Marina A.M., CheMan Y.B., Nazimah S.A., Amin I. (2009) Antioxidant capacity and phenolic acids of virgin coconut oil. Int. J. Food Sci. Nutr. 60(S2): 114-123.

Moguel-Ordóñez Y.B., Cabrera-Amaro D.L., Segura-Campos M.R., Ruiz-Ruiz J.C. (2015) Studies on drying characteristic, nutritional composition, and antioxidant properties of Stevia rebaudiana (Bertoni) leaves. Int. Agrophys. 29: 323-331.

Moigradean D., Poiana M.A., Alda L.M., Gogoasa I. (2013) Quantitative identification of fatty acids from walnut and coconut oils using GC-MS method. J. Agroaliment Proc. Technol. 19(4): 459-463.

Nevin K.G., Rajamohan T. (2006) Virgin coconut oil supplemented diet increases the antioxidant status in rats. Food Chem. 99: 260-266.

Nevin K.G., Rajamohan T. (2010) Effect of topical application of virgin coconut oil on skin components and antioxidant status during dermal wound healing in young rats. Skin Pharmacol. Physiol. 23(6): 290-297.

O'Shea M., Bassaganya-Riera J., Mohede I.C.M. (2004) Immunomodulatory properties of conjugated linoleic acid. Am. J. Clin. Nutr. 79: S1199-1206.

Orsavova J., Misurcova L., Ambrozova J.V., Vicha R., Mlcek J. (2015) Fatty acids composition of vegetable oils and its 
contribution to dietary energy intake and dependence of cardiovascular mortality on dietary intake of fatty acids. Int. J. Mol. Sci. 16: 12871-12890.

Otuechere C.A., Madarikan G., Simisola T., Bankole O., Osho A. (2014) Virgin coconut oil protects against liver damage in albino rats challenged with the anti-folate combination, trimethoprim-sulfamethoxazole. J. Basic Clin. Physiol. Pharmacol. 25(2): 249-253.

Parthipan B., Suky M.G.T., Mohan V.R. (2015) GC-MS Analysis of Phytocomponents in Pleiospermium alatum (Wall. ex Wight \& Arn.) Swingle, (Rutaceae). J. Pharmacogn. Phytochem. 4(1): 216-222.

Peng W.W., Zeng G.Z., Song W.W., Tan N.H. (2013) A new cytotoxic carbazole alkaloid and two new other alkaloids from Clausena excavata. Chem. Biodivers. 10: 1317-1321.

Popova T. (2011) Fatty acid composition and oxidative stability of muscles in lambs fed coconut oil supplemented diet. Bulg. J. Agric. Sci. 17(3): 402-409.

Prades A., Dornier M., Diop N., Pain J.P. (2012) Coconut water uses, composition and properties: a review. Fruits. 67: 87-107.

Ravi L., Krishnan K. (2017) Cytotoxic potential of N-hexadecanoic acid extracted from Kigelia pinnata leaves. Asian J. Cell Biol. 12: 20-27.

Ruiz J.C.R., Ordoñez Y.B.M., Basto A.M., Campos M.R.S. (2015) Antioxidant capacity of leaf extracts from two Stevia rebaudiana Bertoni varieties adapted to cultivation in Mexico. Nutr. Hosp. Aria. 31(3): 1163-1170.

Saiga A., Tanabe S., Nishimura T. (2003) Antioxidant activity of peptides obtained from porcine myofibrillar proteins by protease treatment. J. Agric. Food Chem. 51: 3661-3667.

Saiqa I., Mansoor A., Uzma H., Shehla A., Mehjabeen Sairah H.K. (2014) Phytochemical and in-vitro antioxidant evaluation of different fractions of Amaranthus graecizan ssubsp.
Silvestris (Vill.) Brenan. Asian Pac. J. Trop. Biomed. 4(12): 965-971.

Shankar P., Ahuja S., Tracchio A. (2013) Coconut oil: a review. Agro Food Ind. Hi-Tec. 24(5): 62-64.

Srivastava Y., Semwal A.D., Majumdar A. (2016) Quantitative and qualitative analysis of bioactive components present in virgin coconut oil. Cogent Food Agricult. 2: 1164929.

Thampan P.K. (1988) Glimpses of coconut industry in India. Coconut Development Board, Cochin 1988.

Tylor B.S., Kion Y.M., Wang Q.I., Sharpio R.A., Billiar T.R., Geller D.A. (1997) Nitric oxide down regulates hepatocyteinduible nitric oxide synthase gene expression. Arch. Surg. 132: 1177-1183.

Upgade A., Anusha B. (2013) Characterization and medicinal importance of phytoconstiuents of Carica papayafrom down south Indian region using gas chromatography and mass spectroscopy. Asian J. Pharm. Clinical Res. 6(4): 101-106.

Yeap S.K., Beh B.K., Ali N.M., Yusof H.M., Ho W.Y., Koh S.P. (2015) Antistress and antioxidant effects of virgin coconut oil in vivo. Exp. Ther. Med. 9: 1-39.

Yousefi M., Nateghi L., Rezaee K. (2013) Investigation of physicochemical properties, fatty acids profile and sterol content in Malaysian coconut and palm oil. Ann. Biol. Res. 4(4): 214-219.

Yu F.R., Lian X.Z., Guo H.Y., McGuire P.M., Li R.D., Wang R., Yu F.H. (2005) Isolation and characterization of methyl esters and derivatives from Euphorbia kansui (Euphorbiaceae) and their inhibitory effects on the humanSGC-7901 cells. J. Pharm. Pharm. Sci. 8: 528-535.

Zhang F.F., Gan L.L., Zhou C.H. (2010) Synthesis, antibacterial, and antifungal activities of some carbazoles derivatives. Bioorg. Med. Chem. Lett. 20: 1881-1884. 